\title{
Anti-candidal activities of some M yrtus Communis L. extracts obtained using accelerated solvent extraction (ASE)
}

\author{
Elif Ayse Erdogan ${ }^{1 *}$, Gulden Goksen ${ }^{2}$ and Ayse Everest ${ }^{1}$ \\ ${ }^{1}$ Department of Biology, Mersin University, Mersin -33343, TURKEY. \\ ${ }^{2}$ Department of Food Engineering, Mersin University, Mersin -33343, TURKEY.
}

\section{ARTICLE INFO}

Article history:

Received on: 16/09/2014

Revised on: 29/09/2014

Accepted on: 09/10/2014

Available online: 30/10/2014

\section{Key words:}

Candida albicans, Myrtus communis, ASE (Accelerated

Solvent Extraction), Anti-

candidal.

\begin{abstract}
Candida albicans is a very important organism in production of acute and chronic infections. It can be reason of serious infections in human immune compromised patients as nosocominal infections. In this study, We researched new anti-candida agents from Myrtus communis extracts by ASE (Accelerated Solvent Extraction). We were also determined Gallic, Ferulic, Quercetin phenolic compounds known charged with antimicrobial activity by HPLC (High-performance Liquid Chromatography). Gallic acid (2,424 mg/g) and Quercetin $(2,289$ $\mathrm{mg} / \mathrm{g})$ were detected in high amounts in Acetone extract and Methanol extract while Ferulic $(0,018 \mathrm{mg} / \mathrm{g} ; 0,038$ $\mathrm{mg} / \mathrm{g} ; 0,006 \mathrm{mg} / \mathrm{g}$ ) was recorded in low amounts in Methanol, Ethanol and Ethly acetate extracts, respectively. Methanol, Acetone, Ethanol and Ethly acetate extracts showed good anti-candida activity against $C$. albicans, with Minimum Inhibitory Concentration (MIC) ranging from 0.187 to $1,5 \mathrm{mg} / \mathrm{mL}$; Minimum Fungicidal Concentration (MFC) ranging from 0,375 to $3 \mathrm{mg} / \mathrm{mL}$.
\end{abstract}

\section{INTRODUCTION}

Candidemia is known as the fourth most common nosocominal bloodstream infection. Hence, control of the spread of Candida albicans strains and treatment of infections caused by them is very important problem worldwide [1]. In the past decade, the prevalence of resistant to anticandida agents significantly increased. It makes necessary to discover new agents of anti-candidal compounds to treat infections. In particularly, Herbal agents are important in controlling spread of Candida [2,3]. In traditional medicine, the leaves of Myrtus communis have used mostly in lung and digestive disorders and in the treatment of many types of infectious including candidacies as antiseptic, anti-inflammatory agent, a mouthwash [4]. In recent research, the antifungal effects of extracts of leaves of this plant has been proven. Numerous studies have been devoted to the extraction of Myrtus communis leaves [5-8]. In particularly, Phenols in leafs is considered to be main biologically active antimicrobial chemicals produced. In vitro experiments have proved its inhibiting effect on Candida albicans which known the most frequent human infections $[9,10]$. The aims of the present study were to determined the anticandidal activities of four extracts of Myrtus communis obtained with ASE and researched phenolic component of extracts.

\footnotetext{
* Corresponding Author

Department of Biology, Mersin University, Mersin -33343, TURKEY .

Mail id: eliferdogan81@gmail.com,Tel:05072089428
}

\section{MATERIALS AND METHODS}

\subsection{Plant material}

Aerial parts of Myrtus communis were collected in May from Mersin, Turkey and botanical identification of the plant was done by Prof. Ayse Everest at Mersin University Biology Department.

\subsection{Preparation of Extracts}

The extractions of soluble compounds from Myrtus communis by Accelerated Solvent Extraction were performed by using methanol, ethanol, acetone, ethyl acetate as a solvent. The below method was modified by ASE [11].

Aliquots of Myrtus communis leafs $(2,4 \mathrm{~g})$ were grounded in cold-blender, passed the through a 20 mesh sieve to acquire particles size of $<2 \mathrm{~mm}$, mixed and dispersed with diatomaceous earth (1:1) to remove moisture. Then, the samples were placed in a $66 \mathrm{~mL}$ stainless steel extraction cell, to perform extractions with solvents on a ASE 150 (Dionex) system.

The dry plant sample $(2,4 \mathrm{~g})$ was extracted by one extraction cycles with all solvent $(\% 99$ pure $)$ at $100^{\circ} \mathrm{C}, 1500 \mathrm{psi}$ during $5 \mathrm{~min}$.

Then, the cell was rinsed with fresh extraction solvent and purged with a flow of nitrogen (150 psi during $90 \mathrm{~s}$ ). The final of the experiment, the extraction solution was collected in $66 \mathrm{~mL}$ glass vials. This prosedure was performed for all of the solvent, separately. The extracts were filtered (with a $0.45 \mu \mathrm{m}$ membrane) and stored at $-20^{\circ} \mathrm{C}$ in darkness until HPLC and microbial analysis. 


\subsection{Analysis of Extracts using HPLC}

The main compounds of extracts researched on Agilent 1200 HPLC equipment with a autosampler, a DAD, column under the optimum condition modified by Mradu's method [12]. The Column was phenomenex C-18, $3 \mu \mathrm{m}$ particle size $(50 \times 4.6 \mathrm{~mm}$ I.D) type. The condition of HPLC; total run time was 45 minutes, Gradient elution - Solvent A (Acetonitrile) and Solvent B (0.1\% Phosphoric acid in water), program was begun with $85 \% \mathrm{~B}$ and was held at this concentration for the first 12 minutes, followed by $75 \%$ eluent B for the next 10 minutes after which its concentration was again increased to $85 \%$ for the next 8 minutes. The flow rate was $20 \mathrm{ml} / \mathrm{min}$, the injection volume was $20 \mu \mathrm{l}$, monitored and quantified at $280 \mathrm{~nm}$.

The phenolic compounds of extracts were calculated by the formula:

$C_{x}(\mu \mathrm{g} / \mathrm{g})=A_{x}$ x $C_{s}(\mu \mathrm{g} / \mathrm{ml})$ x V $(\mathrm{ml})$ : As x Sample weight (g)

Where $C_{x}$ is the concentration of the phenolic $\mathrm{X}, A_{x}$ is the peak area of the phenolic X, $C_{s}$ is the concentration of the Standard and $A_{s}$ is the peak area of the Standard [13].

\subsection{Anti-candida activity of Extracts}

The extracts of Myrtus communis were tested against Candida albicans (clinic strain) to MIC (Minimal Inhibitory Concentration) and MFC (Minimum Fungicidal Concentration). MIC, lowest concentration causing complete visible growth inhibition, and MFC, lowest concentration killing 99.9\% cells, were determined by broth microdilution method modified by Dabur and Zore [14, 15]. The yeast inoculum was prepared in $4 \mathrm{ml}$ triptic soy broth medium, incubated at $37{ }^{\circ} \mathrm{C}$ and in sabouraud dextrose broth medium at $28{ }^{\circ} \mathrm{C}$ for $24 \mathrm{~h}$ before being used overnight, respectively. The culture, 12 hour-cultures were adjusted to 0.5 McFarland Standard Turbidity $\left(\sim 10^{3}\right.$ for yeast colony forming unit (CFU) per milliliter [16]. Two-fold serial dilutions of extracts of Myrtus communis were added to the wells of a 96-well microtiter plate. $100 \mu \mathrm{l}$ of each dilution, ranging from 24 to $0,1 \mathrm{mg} / \mathrm{ml}$ were mixed with an equal volume of bacterial suspension $(25 \mu \mathrm{l})$. Fluconazole antibiotic was used as positive reference standards for yeast. Then, The plates were incubated for 36 hours at $37^{\circ} \mathrm{C}$ and observed visually for growth (turbidity) inhibition to determine MIC. $5 \mu 1$ culture of all wells was inoculated on YPD agar plates for 36 hours at $37^{\circ} \mathrm{C}$ for determine MFC.

\section{RESULTS AND DISCUSSION}

Myrtus communis selected for anti-candida activity have been used in traditional medicine for the treatments of related infections. The phenolic content and antimicrobial effect values of some M.communis extracts against $C$. albicans were presented in Table 1. C. albicans was found sensitive to positive control (Fluconazole). We reported all solvents were toxic more than $>12,5 \mathrm{mg} / \mathrm{ml}$ of concentration for Candida albicans cultures. Hence, for the antimicrobial activity, M. communis concentrations which solvent's was not toxic were noted. We reported the Ethanol, methanol, acetone, ethyl acetate extracts showed good activity against $C$. albicans tested with MIC values ranging from 0.187 to $1,5 \mathrm{mg} / \mathrm{mL}$; MFC ranging from 0,375 to $3 \mathrm{mg} / \mathrm{mL}$. After 36 hours the ranges of MIC obtained with methanol, ethanol, ethyl acetate, acetone extracts were $1,5 \mathrm{mg} / \mathrm{ml} ; 0,75 \mathrm{mg} / \mathrm{ml} ; 0,375$ $\mathrm{mg} / \mathrm{ml} ; 0,187 \mathrm{mg} / \mathrm{ml}$; MFC were $3 \mathrm{mg} / \mathrm{ml} ; 1,5 \mathrm{mg} / \mathrm{ml} ; 0,75 \mathrm{mg} / \mathrm{ml}$; $0,375 \mathrm{mg} / \mathrm{ml}$, respectively.

Table. 1: The main components of Myrtus communis Extracts using HPLC and Minimal Inhibitory and Fungicidal Concentration of Extracts against Candida albicans.

\begin{tabular}{|c|c|c|c|c|}
\hline & Comp. mg/g & Ret. time & $\begin{array}{l}\text { MIC } \\
\mathrm{mg} / \mathrm{mL}\end{array}$ & $\begin{array}{l}\text { MFC } \\
\mathrm{mg} / \mathrm{mL}\end{array}$ \\
\hline \multirow{3}{*}{ Methanol Ext. } & Gallic 0,01 & 3.553 & \multirow{3}{*}{1,5} & \multirow{3}{*}{3} \\
\hline & Quercetin 2,289 & 4.225 & & \\
\hline & Ferulic 0,018 & 16.734 & & \\
\hline Ethanol Ext. & $\begin{array}{l}\text { Gallic } 0,019 \\
\text { Ferulic } 0,038\end{array}$ & $\begin{array}{l}3.595 \\
16.706\end{array}$ & 0,75 & 1,5 \\
\hline Ethyl acetate Ext. & $\begin{array}{l}\text { Quercetin } 0,336 \\
\text { Ferulic } 0,006\end{array}$ & $\begin{array}{l}3.934 \\
16.771\end{array}$ & 0,375 & 0,75 \\
\hline Acetone Ext. & Gallic 2,424 & 3.551 & 0,187 & 0,375 \\
\hline
\end{tabular}

Ext: Extraction, Comp: Component, MIC: Minimal Inhibitory Concentration, MFC: Minimum Fungicidal Concentration, Ret.Time: Retention Time. All experimets were performed in five times and averaged.

We reported that all of the extracts in this study had a favorable anti-candidal activity. Acetone extract exhibited strongest activity against $C$. albicans with MIC value of 0,187 and MFC value of $0,375 \mathrm{mg} / \mathrm{ml}$. Concordantly, Gallic acid was found the main component of acetone extract $(2,424 \mathrm{mg} / \mathrm{g})$. The lowest activity (MIC: $1,5 \mathrm{mg} / \mathrm{ml}$ and MFC: $3 \mathrm{mg} / \mathrm{ml}$ ) were recorded in methanol extract and the quercetin $(2,289 \mathrm{mg} / \mathrm{g})$ were found the main component. Ferulic acid were found in methanol $(0,018 \mathrm{mg} / \mathrm{g})$, ethanol $(0,038 \mathrm{mg} / \mathrm{g})$ and ethyl acetate $(0,006 \mathrm{mg} / \mathrm{g})$ extracts in low amounts while it was not determined in asetone extract. Other studies have shown mostly that essential oils of plant had strong antimicrobial activity [17-20]. However, It has known that classical extraction methods commonly used for the evaluation of antifungal activities of Myrtus communis. In literature, Bajur and his colleagues reported the methanol extract of Myrtus communis leaves had antifungal activity with MIC: $0,31 \mathrm{mg} / \mathrm{mL}$ [21]. It was also shown that alcoholic extract of Myrtus communis had different degrees growth inhibition, depending on the Candida albicans strains between $25 \mathrm{mg} / \mathrm{ml}$ and $2.5 \mathrm{mg} / \mathrm{mL}$ [22]. These studies support our study with regard to strong biological activity. Accelerated Solvent Extraction techology was firstly used for evaluation of anticandidal activity of Myrtus communis in this study. In previous works, ASE process have been optimized for the extraction of phenolics from Basque Sider apple, Eggplant and Black Cohosh [23-25]. This method is highly advantageous, fast and reliable for plant tissues [26]. Our results corroborate the importance of Accelerated Solvent Extraction (ASE) in the selection of methods for bioactivitiy screening.

\section{CONCLUSION}

In sum, We researched for the first time anticandidal activity of $M$. communis extracts obtained using ASE. Datas showed all of the extracts of M. Communis had strong anticandidal 
activity. We were determined some phenolics (Gallic, Ferulic, Quercetin) were abundant in these extracts. We assume the inhibitory effects of the extracts increased due to ASE process. Hence, there is need further researches to expose components of extracts.

\section{ACKNOWLEDGMENTS}

This study was supported by Science Institute of Mersin University and MEITAM (Mersin University Advenced Technology Education, Research and Aplication Center). The authors thank the workers of Assist. Prof. Deniz AYAS, Chemistry expert Cihan GECGEL, Biology expert Ersin OZTURK.

\section{REFERENCES}

1. Cannas S, Molicotti P, Ruggeri M, Cubeddu M, Sanguınetti M, Marongiu B, Zanetti S. Antimycotic activity of Myrtus communis L. towards Candida spp. From clinical isolates. The journal of Infection in Developing Countries. 2013; 7(3): 295-298.

2. Khan ZU, Chandy R, Metwali KE. Candida albicans strain carriage in patients and nursing staff of an intensive care unit: a study of morphotypes and resistotypes. Mycoses. 2003; 46 (11): 476-486.

3. Khan R, Zakir M, Afaq SH, Latif A, Khan, AU. Activity of solvent extracts of Prosopis spicigera, Zingiber officinale and Trachyspermum ammi against multidrug resistant bacterial and fungal strains. Journal of Infection in Developing Countries. 2010; 4(5): 292-300.

4. aleksic v, knezevic pA. Antimicrobial and antioxidative activity of extracts and essential oils of Myrtus communis L. Microbiological Research. 2013; 169 (2014): 240-254.

5. Clark AM. Natural products as a resource for new drugs. Pharmaceutical Research, 1996; 13(8): 1133-1144.

6. Michael EK, pharm D. Antifungal resistance among Candida species. Pharmacotherapy. 2001; 21(8): 124-132.

7. Alem G, Mekonnen $\mathrm{Y}$, Tiruneh M, Mulu A. In vitro antibacterial activity of crude preparation of myrtle (Myrtus communis) on common human pathogens. Ethiopian Medical Journal. 2008; 46(1): 63-69.

8. Deriu A, Branca G, Molicotti P, Pintore G, Chessa M, Tirillini B, Paglietti B, Mura A, Sechi LA, Fadda G, Zanetti S. In vitro activity of essential oil of Myrtus communis L. against Helicobacter pylori. International Journal of Antimicrobial Agents. 2007; 30(6): 562-563.

9. Viejo-Diaz M, Andres MT, Fierro JF. Different Anti-Candida activities of two human Lactoferrin-Derived Peptides, Lfpep and Kaliocin-1. Antimicrobial Agents and Chemotherapy. 2005; 49(7): 2583-2588.

10. Zia MA, Bayat M, Khalkhali H, Saffari S. Effect of Thymus vulgaris, Myrtus communis and nystatin on Candida albicans. Journal of Gorgan University of medical Sciences. 2014; 15(4): 59-65.

11. Accelerated solvent extraction (ASE). http://www.dionex.com/enus/products/sample-preparation/ase/instruments/lp-72864.html.

12. Mradu G, Saumyakanti S, Sohını M, Arup M. HPLC Profiles of Standard phenolic compounds present in medicinal plants. International Journal of Pharmacognosy and Phytochemical Research. 2012; 4(3): 162-167.

13. Hart DJ, Scott KJ. Development and evaluation of an HPLC method for the analysis of carotenoids in foods, and the measurement of the carotenoid content of vegetables and fruits commonly consumed in the UK. Food Chemistry. 1995; 54 (1): 101-111.
14. Dabur R, Gupta A, Mandal TK, Deepak Singh D, Bajpai Gurav AM, Lavekar GS. Antimicrobial activity of some Indian medicinal plants. Afr. J. Traditional Complementary and Alternative Medicines. 2007; 4(3): 313-318.

15. Zore GB, Thakre Rathod V, Karuppayll SM. Evaluation of antiCandida potential of geranium oil constituents against clinical isolates of Candida albicans differentially sensitive to fluconazole: inhibition of growth, dimorphism and sensitization. Mycoses. 2010; 54: 99-109.

16. Mcfarland J. Standardizasyon bacteria culture for the disc diffusion assay. Journal of American Medical Association, 1987; 49: 11761178.

17. Mansouri S, Foroumadi A, Ghanei T, Najar AG. Antibacterial activity of the crude extracts and fractionated constituents of Myrtus communis. Pharmaceutical Biology. 2001; 39 (5): 399-401.

18. Yadegarinia D, Gachkar L, Rezaei MB, Astanch SA, Rasooli I. Biochemical activities of Iranian Mentha piperita and Myrtus communis L. essential oils, Phytochemistry, 2006; 67(12): 12491255.

19. Ghannadi A, dezfuly N. Essential oil analysis of the leaves of Persia True Myrtle. International Journal of Medicinal and Aromatic Plants. 2011; 1(2): 48-50.

20. Tayoub G, Abu Alnaser A, Ghanem I. Fumigant activity of leaf essential oil from Myrtus communis L. against the Khapra Beetle. International Journal of Medicinal and Aromatic Plants, 2012; 2(1): 207-213.

21. Sahidi Bonjar GH. Anti-yeast activity of some plants used in traditional herbal medicine of Iran. Journal of Biological Sciences. 2004; 4(2): 212-215.

22. Issazadeh K, Massiha A, Pahlavianı MRMK. Minimum inhibitory concentration (MIC) of Myrtus communis extract and nystatin on clinical isolated and standard strains of Candida albicans. Journal of Applied Environmental and Biological Sciences. 2012; 2 (9): 466468.

23. Alonso-salces RM, Korta E, Barranco L, Berrueta LA, Gallo B, Vicente F. Determination of polyphenolic profiles of Basque Cider Apple varieties using Accelerated Solvent Extraction. Journal of Agricultural and Food Chemistry. 2001; 49: 3761-3767.

24. Luthria DL, Mukhopadhyay S. Influence of sample preparation on assay of phenolic acids from eggplant. Journal of Agricultural and Food Chemistry. 2006; 54: 41-47.

25. Mukhopadhyay S, Luthria DL, Robbins R. Optimization of extraction process for phenolic acids from black cohosh (Cimicifuga racemosa) by pressurized liquid Extraction. Journal of the Science of Food and Agriculture. 2006; 86: 156-162.

26. Hossain MB, Barry-Ryan C, Martin-Diana AB, Brunton NP. Optimisation of accelerated solvent extraction of antioxidant compounds from rosemary (Rosmarinus officinalis L.), marjoram (Origanum majorana L.) using response surface methodology. Food Chemistry, 2011; 126 (1): 339-346.

\section{How to cite this article:}

Elif Ayse Erdogan, Gulden Goksen and Ayse Everest. Anticandidal Activities Of Some Myrtus Communis L. Extracts Obtained Using Accelerated Solvent Extraction (ASE). J App Biol Biotech. 2014; 2 (05): 012-014. 